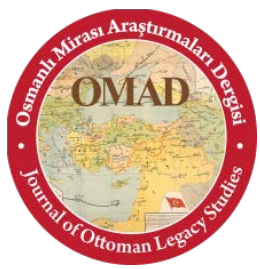

Osmanlı Mirası Araştırmaları Dergisi (OMAD), Cilt 3, Sayı 6, Temmuz 2016, ss. 60-72.

Journal of Ottoman Legacy Studies (JOLS), Volume 3, Issue 6, July 2016, pp. 60-72.

ISSN 2148-5704

DOI Number: 10.17822/omad.2016620349

\title{
25452 NUMARALI GÜMRÜK DEFTERİNE GÖRE KİLİ NEZARETİ GÜMRÜĞÜ
}

\section{Kili Nezareti Customs Office According to the Customs Notebook, No: 25452}

\section{Mustafa IŞIK*}

\begin{abstract}
Özet: Kili, Tuna Nehri’nin Karadeniz’e döküldüğü bölgede yer almaktadır. Kili bu coğrafi konumundan dolayı Tuna Nehri ve Karadeniz vasıtasıyla Avrupa ile Asya arasında köprü oluşturan önemli bir liman şehridir. Bu çalışmada Başbakanlık Osmanlı Arşivi'nde yer alan 25452 numaralı gümrük defterindeki veriler 1şığında Kili Nezareti Gümrügü̆nün XVIII. yüzyılın sonlarındaki gelir ve giderleri değerlendirilmiş ve Kili gümrüğünün esir ticaretinde de önemli bir yere sahip olduğu tespit edilmiştir.
\end{abstract}

Anahtar Kelimeler: Kili Gümrüğü, Tuna ve Karadeniz ticareti, pençik resmi

Abstract: Kili is located in the region where Danube River runs down to Black Sea. Because of its geographical location, Kili is an important port town which forms a bridge between Europe and Asia via Danube River and Black Sea. In this study; in the light of the data acquired from the customs notebook no:25452 in Prime Ministry Ottoman Archive; income and expenses of Kili Nezareti Customs Office in the late 18th century have been evaluated and it has been determined that Kili Customs Office also had an importance place in prisoner trade.

Key Words: Kili Customs Office, Danube and Black Sea trade, pençik tax

\section{Kili’nin Kısa Tarihçesi}

Tuna Nehri'nin Karadeniz'e döküldüğü bölgede yer alan Kili'nin tarihi, XII. yüzyıla kadar gitmektedir. Bizans İmparatorluğu döneminde ticaret merkezi olan şehir, akabinde Cenevizlilerin hâkimiyetine girmiştir. Baltık Denizi’nden başlayarak İstanbul'a kadar uzanan Boğdan Ticaret Yolu'nun Kili'den geçmesi şehrin önemini arttırmıştır. Şehirde Osmanlı hâkimiyeti ilk önceleri dolaylı olarak kurulmuştur. Zira Dobruca Voyvodası İvanko 1371 yılında Osmanlı hâkimiyetini kabul etmişti. Ancak 1402 y1lında Yıldırım Bayezid'in Ankara Savaşı'ndaki yenilgisi üzerine Kili, Eflak Beyi Mircea'nın eline geçmiştir. Yıldırım Bayezid'den sonra Anadolu'daki birliği yeniden sağlayan Çelebi Mehmed, 1419 yılında Lehistan üzerine düzenlediği seferde Eflak'a girerek Voyvoda Mircea'ya Osmanlı hâkimiyetini kabul ettirmiştir. Osmanlı orduları bu sefer esnasında Kili ve Akkirman kalelerini kuşatmışlar ancak ele geçirememişlerdir. ${ }^{1}$ Fatih Sultan Mehmet döneminde Karadeniz sahillerinin dörtte üçünü ele geçirmiş olan Osmanlıların hem ticaret hem de Lehistan seferleri için Kili ve Akkirman gibi önemli üs olan şehirlerin alınması gerekmekteydi. Bunun için II. Bayezid tahta geçtikten sonra 1483 yılında Lehistan, Macaristan ve Venedik ile barış yaparak Boğdan üzerine sefer için uygun bir zemin sağlamıştır. ${ }^{2}$

\footnotetext{
* (Yrd. Doç. Dr.), Mustafa Kemal Üniversitesi, Fen-Edebiyat Fakültesi, Tarih Bölümü, Hatay/Türkiye, e-mail: egeli21@hotmail.com

${ }^{1}$ Mihai Maxim, "Kili”, DİA, C. XXVI, İstanbul 2002, s. 1.

2 İsmail Hakkı Uzunçarşıll, Osmanlı Tarihi, Cilt II, Türk Tarih Kurumu Basımevi, Ankara 1998, s. 181.
} 
Halil İnalcık, II. Bayezid'in saltanatını güçlendirmek için büyük bir gazaya niyetlendiğini bunun için de bilhassa babası Fatih'in başarısız olduğu ${ }^{3}$ Boğdan'ı seçtiğini ifade etmektedir. ${ }^{4}$ Ancak Boğdan Seferi için Nicolae Jorga, muhtemelen Mihaloğlu Ali Bey'in padişaha, Karadeniz'deki Osmanlı hâkimiyetini sağlamlaştırmak için öncelikle Kili ve Akkirman limanlarının fethedilmesi gerektiği şeklinde telkinde bulunduğunu belirtmektedir. ${ }^{5}$

Sultan II. Bayezid, Cem Sultan meselesi ile meşgul iken Boğdan Kralı, Eflak'a saldırınca 1484 yılında Boğdan üzerine sefere çıkmıştır. II. Bayezid'in Boğdan Seferi'nde Kırım Hanı Mengli Giray ve Eflak voyvodası da Osmanlı Sultanının yanında yer almışlardır. ${ }^{6}$ Osmanlı kuvvetleri Boğdan'ın Karadeniz'e açılan kapısı durumundaki Kili Kalesi'ni hem karadan hem de denizden kuşatmıştır. ${ }^{7}$ Kale, II. Bayezid tarafından on günlük ${ }^{8}$ kuşatma sonucunda 15 Temmuz 1484 tarihinde fethedilmiştir. Hemen ardından da Akkirman Kalesi Osmanlılar tarafından fethedilmiștir. ${ }^{9}$ Böylece Osmanlı Devleti hem İstanbul'un iașesi için çok önemli olan Karadeniz ve Tuna mansabını kontrol altına almış hem de Karadeniz'i Baltık Denizi’ne bağlayan Boğdan Ticaret Yolu'nun kontrolünü ele geçirmiştir. ${ }^{10}$ Osmanlı fethinden sonra Kili sancak hâline getirilip kale ve varoşuna kapıkulları ile azepler yerleştirilmiştir. ${ }^{11}$ Fetihten sonra şehirdeki kiliseler camiye çevrilmiş ve şehri terk etmek istemeyen gayrimüslimlere engel olunmamıştır. ${ }^{12}$ Şehre giren II. Bayezid, balıkçılardan, köylülerden ve tüccarlardan oluşan nüfusa dokunmamıştır. Kili'nin fethiyle birlikte buradaki ham deri, peynir, salamura ve Kili yünlerinden oluşan gümrük gelirleri artık Türk yetkililer tarafından tahsil edilmeye başlanmıştır. ${ }^{13}$

II. Bayezid, Kili ve Akkirman'ın fethiyle kuzey memleketlerinin Akdeniz ile ticaretini sağlayan bu iki önemli şehri hâkimiyeti altına almıştır. Böylece, Boğdan Voyvodası Stefan da kesin olarak Osmanlı hâkimiyetini tanımıştır. ${ }^{14}$ Ayrıca II. Bayezid bu suretle Boğdanlıların Karadeniz'de yaptıkları korsanlıklara da engel olma yolunda önemli bir adım atmıştır. ${ }^{15}$ Kili ve

\footnotetext{
${ }^{3}$ Fatih Sultan Mehmet'in Ştefan Çel Mare üzerine yaptığı seferler hakkında detaylı bilgi için bkz. Mihail Guboğlu, "Fatih'in Ştefan Çel Mare Üzerine İki Boğdan Seferi (1474-1476)”, Belleten, C. XLVII, S. 185, Ankara 1984, s. 138-94.

${ }^{4}$ Halil İnalcık, Devlet-i 'Aliyye-Osmanlı İmparatorluğu Üzerine Araştırmalar I, Türkiye İş Bankası Kültür Yayınları, İstanbul 2009, s. 131.

${ }^{5}$ Nicolae Jorga, Osmanlı İmparatorluğu Tarihi, C. II, çev. Nilüfer Epçeli, Yeditepe Yayınları, İstanbul 2009, s. 2312 .

${ }^{6}$ Mustafa Nuri Paşa, Netayicü'l-Vukuat, C. I-II, sad. Neşet Çağatay, Türk Tarih Kurumu Basımevi, Ankara 1992, s. 53.

${ }^{7}$ Uzunçarşıll, a.g.e., s. 182; Joseph Von Hammer, Osmanlı İmparatorluğu Tarihi, C. I, İlgi Kültür Sanat Yayınları, İstanbul 2007, s. 339.

${ }^{8}$ Osmanlı kroniklerinde şehrin on günlük bir kuşatmanın ardından fethedildiğinden bahsedilirken Romen tarihçi Nicolae Jorga, kalenin 8 günlük kuşatma sonucunda alındığını belirtmektedir. Bkz. Jorga, a.g.e., s. 232. Uzunçarşılı ise 9 gün kuşatmadan sonra Kili Kalesi'nin fethedildiğini belirtmektedir. Bkz. Uzunçarşıl1, a.g.e., s. 182.

${ }^{9}$ Kili ve Akkirman'ın fethi, Tacü't-Tevarih'te uzun uzun anlatılmaktadır. Buna göre II. Bayezid, Edirne'de hayır ve hasenat işlerini tamamladıktan sonra ordusuyla birlikte Dobruca üzerinden Tuna kıyısında İshaklı veya İshakçı adı verilen iskeleye gelmiştir. Burada II. Bayezid'i daha önce yolladığı donanma bekliyordu. Zira II. Bayezid, Kili ve Akkirman seferine çıkmadan önce daha İstanbul'da iken asker, mühimmat ve erzak yüklü donanma-i hümayunu Tuna ağzına gitmesi ve orada kendisini beklemesi için yola çıkarmıştı. II. Bayezid işte bu gemiler ile İshakçı veya İshaklı adı verilen iskeleden Tuna Nehri üzerinden karşıya geçmiştir. Burada Osmanlı'ya tabi olan Eflak Beyi 20.000 askeriyle birlikte padişahı karşılamış ve orduya rehberlik etmiştir. Böylece Osmanlı ordusu Rebiülevvelin 11. günü Kili önlerine gelmiş ve kaleyi kuşatma altına almıştır. 10 günlük bir kuşatmadan sonra Kili Kalesi aman dileyerek teslim olmuştur. Bkz. Hoca Sadettin Efendi, Tacü't-Tevarih, haz. İsmet Parmaksızoğlu, C. II, Kültür Bakanlığı Başvuru Kitapları, Eskișehir 1992, s. 236-8.

${ }^{10}$ Mihai Maxim, “Tuna”, DİA, İstanbul 2012, C. XLIV, s. 373.

${ }^{11}$ M. Maxim, “a.g.m”, s. 1.

12 Mehmed Neşri, Neşri Tarihi, haz. Mehmet Altay Köymen, C. II, Kültür ve Turizm Bakanlı̆̆ı Yayınları, Başbakanlık Basımevi, Ankara 1984, s. 212.

${ }^{13}$ Jorga, a.g.e., s. 232.

${ }^{14}$ H. İnalc1k, a.g.e, , s. 131.

${ }^{15}$ Dimitri Kantemir, Osmanlı İmparatorluğu'nun Yükseliş ve Çöküş Tarihi, düz. Erkan Ünlücan, C. I, İstanbul 2002, s. 176.
} 
Akkirman limanlarının fethiyle birlikte Karadeniz fiilen bir "Osmanlı Gölü” hâline gelmiştir. Bundan sonra da Kili ve Akkirman limanları pamuklu mallar, ipekli mallar, yünlüler, tahıl, meyve, ham ve işlenmiş madenler, deri, post, baharat, şeker, bal, boya ve şap gibi metaların ticareti için ${ }^{16}$ Tuna-Karadeniz ticaretinin önemli bir merkezi ve diğer Tuna iskelelerinden İstanbul'a gönderilecek mallar için kavşak noktası hâline gelmiştir. ${ }^{17}$

\section{Karadeniz Ticareti ve Kili Gümrüğü}

Karadeniz havalisi, eskiçağlardan beri İstanbul ve Çanakkale Boğazları vasıtasıyla Ege ve Akdeniz arasında yoğun bir ticari bağlantıya sahipti. ${ }^{18}$ Esasen Karadeniz, Akdeniz'in bir parçası olarak eski dünyanın ve Akdeniz'in siyasi ve ticari hayatında sürekli yer almıştır. ${ }^{19}$ Karadeniz, İskit-Sarmat kavimleri ve Yunan Anadolu kavimlerinden başlayarak her zaman Asya ve Avrupa arasında bağlantı sahası olmuștur. IV. yüzyılda Karadeniz havalisi ile Hazar Denizi arasında doğudaki Türklerin gelmesiyle de Asya'nın iç kısımları ile bağlantı kurulmuştur. ${ }^{20}$ Fenikeliler ve hemen ardından Yunanlılar Karadeniz'de ticaret kolonileri kurmuş ve buralarda ticari faaliyetlere başlamışlard. ${ }^{21}$ Daha sonra İstanbul'un Doğu Roma İmparatorluğu'nun merkezi olması hasebiyle Karadeniz'in hem siyasi hem de ticari açıdan önemi artmıştır. ${ }^{22}$ Avrupa ile Asya arasındaki ticarette Karadeniz ile birlikte Tuna Nehri de çok önemli bir yere sahiptir. Zira deniz yollarının keşfinden önce Orta Çağ'da Hindistan'ın servetine ulaşma ümidinde Tuna ticareti önemli bir yer tutmaktayd. İtalya'dan başlayan ana ticaret yolu Bavyera Augsburg, Regensburg ve Viyana'dan geçmekteydi. Bu ticaret yolu Ren Nehri üzerinden Almanya'nın içlerine ve Hansa şehirlerine de ulaşmaktaydı. Öyle ki Tuna Nehri üzerinde yer alan Regensburg, Güney Almanya için uzun süre Hint ve Levant ticaretinin antreposu olarak kalmıştır. ${ }^{23}$

XIII. yüzyılda Eski Dünya'nın merkezi olan Avrupa ve Akdeniz Havzasını, Asya'ya bağlayan kuzey, orta ve güney yolu olmak üzere üç ana ticaret yolu vardı. Bunlardan kuzey yolu İstanbul üzerinden Karadeniz kıyılarına oradan da Orta Asya'ya ulaşıyordu. İkinci yol olan orta yol ise Akdeniz, Anadolu, Suriye, Irak ve İran üzerinden Basra Körfezi'ne oradan da Hint Okyanusu'na bağlanmaktaydı. Güneydeki yol ise Akdeniz, İskenderiye, Kahire ve Kızıldeniz vasıtasıyla Umman Denizi üzerinden Hint Okyanusuna bağlanıyordu. XIII. yüzyılda Moğollar Karadeniz Havalisi ile Anadolu'nun büyük bir kısmını egemenliklerine alarak kıtalararası ticaret yollarına sahip olmuşlardır. ${ }^{24} \mathrm{Bu}$ coğrafyada tesis edilen Moğol Barışı (Pax Mongolica) sayesinde yukarıda sözü edilen üç ana ticaret yollarından kuzey ve orta yol olmak üzere ikisi ticari yönden ciddi bir şekilde canlanmış ve doğu-batı ticaretinde en önemli iki güzergâh hâline gelmiştir. ${ }^{25} \mathrm{Bu}$ bilgilere istinaden Karadeniz ticaretinin Moğol Barışı döneminde özel bir gelişme gösterdiğini söyleyebiliriz.

Karadeniz üzerinden sadece doğu-batı ticaret yolu geçmemekteydi. Bilakis kuzey-güney eksenli bir yol daha geçiyordu. Kuzeyde Alman Hansa Ticari Birliklerinin Kuzey Denizi ve Baltık Denizi'ni ticari açıdan canlandırmaları neticesinde önceden de var olan İstanbul-Baltık Denizi ticaret yolunun önemi daha da artmıştır. Çünkü kuzeyde Almanların bu ticari faaliyetleri

\footnotetext{
${ }^{16}$ Caroline Finkel, Rüyadan Imparatorluğa Osmanlı Imparatorluğu'nun Öyküsü 1300-1923, çev. Zülal Kılıç, Timaş Yayınları, İstanbul 2010, s. 64-5.

${ }^{17}$ M. Maxim, “a.g.m”, s. 2.

${ }^{18}$ DİA Komisyonu, "Karadeniz", DİA, C. XXIV, İstanbul 2001, s. 387.

${ }_{19}$ Ahmet Ardel, "Karadeniz”, IA, C. VI, Eskișehir 1997, s. 235.

${ }^{20}$ Aurel Decei, “Karadeniz (Tarih)”, İ, C. VI, Eskişehir 1997, s.238-46.

${ }^{21}$ Kerim İlker Bulunur, “Osmanlı Dönemi Karadeniz Ticaret Tarihine Katkı: Akkirman Gümrüğü (1505)”, Omeljan Pritsak Armă̆anı, Sakarya Üniversitesi, 2007, s. 525.

${ }^{22}$ Ardel, “a.g.m.”, s. 235.

${ }^{23}$ Adelbert Müller, Die Donau vom Ursprunge bis zu den Mündungen, Verlag von G.Joseph Manz, Regensburg 1839, s. LX.

${ }^{24}$ Şevket Pamuk, Osmanlı Imparatorluğu'nda Paranın Tarihi, Tarih Yurt Vakfı Yayınları, İstanbul 2012, s. 26.

${ }^{25}$ Pamuk, a.g.e., s. 32-3.
} 
Akdeniz ve Karadeniz'de etkin olan İtalyanların ticaretlerine büyük darbe vurmuş ve dünya ticaret merkezi kuzeye kaymıştır. ${ }^{26}$ İstanbul'dan Baltık Denizi'ne giden ticaret yolunun güzergâhını W. Heyd şu şekilde belirtmektedir; "Önce Dniepr Nehri boyunca yukarıya çıkılıyor, sonra Lovat'a varmak için bu nehirden uzaklassllyyor, oradan Lovat Nehri takip edilerek de İmen gölüne kadar iniliyordu. Buradan da Volkof Nehri'ni takiben Ladoga Gölü'ne varllyyor ve nihayet Neva yoluyla Baltık Denizi'ne erişiliyordu." ${ }^{27}$ Ruslar bu ticaret yolu vasitasiyla İstanbul'a deri, balmumu ve savaş esiri getirip satarken, İstanbul'dan ise geri dönüşte sinırlı miktarda ipekli kumaş almaktaydılar. ${ }^{28}$

Tuna Nehri ${ }^{29}$ ağızlarının kuzey kolunda Orta Çağ boyunca Venedik ve Cenevizlilerin sık sık uğradıkları ve bir hububat deposu olarak ve İtalyanlar tarafindan "Licostomo" ismi verilen bir şehir bulunmaktaydı. Bu şehir yakınlığından dolayı Kili ile karıştırılmıştır. Bazı tarihçiler Licostomo'nun yeni adının Kili olduğunu belirtseler de W. Heyd bunun yanlış olduğunu beyan etmektedir. Kili şehri ancak Orta Çağ’ın sonlarına doğru Licostomo'nun yanında haritalarda yer almıştır. ${ }^{30}$

XIII. yüzyılın son çeyreğinden itibaren İtalyan şehir devletlerinin özellikle de Cenevizlilerin Karadeniz ticaretinde öne çıktıkları bilinmektedir. ${ }^{31}$ W. Heyd, XIV. yüzyılın sonunda Bulgaristan topraklarının Osmanlılar tarafindan fethinin tamamlanması ile Tuna ağızlarının güneyindeki Ceneviz hâkimiyetinin de sona erdiğini belirtmektedir. ${ }^{32}$ Her ne kadar Karadeniz'deki Ceneviz hâkimiyeti sona ermiş olsa da XVI. yüzyılın sonlarına kadar Karadeniz'de İtalyan gemicileri faaliyetlerini sürdürmüşlerdir. ${ }^{33}$

1475'te Kefe'nin, 1484'te ise Kili ve Akkirman'1n Osmanlı Devleti tarafindan fethedilmesinden sonra genel anlamda Karadeniz ticareti Osmanlıların eline geçmiştir. Osmanlı hâkimiyeti döneminde Karadeniz'deki Kuzey-Güney ticaret yolu Akkirman-Lviv üzerinden Baltık Denizi'ne çıkıyordu. Osmanlı Döneminde kuzey-güney eksenli bu yol Bursa'yı denizden İstanbul-Karadeniz-Kefe üzerinden Akkirman ve Lviv'e bağlıyordu. Akkirman'dan sonra bu yol, Boğdan Yolu ismini almaktadır. Boğdan Yolu'nun bir diğer kolu da İstanbul'u Edirne ve Kili üzerinden Akkirman'a bağlayan kara yoludur. ${ }^{34}$

Karadeniz'in kuzey kesimlerinde bol miktarda üretilen tahıl, et, balık ve diğer hayvansal ürünler Boğdan ve Kırım'ın sahil şeridindeki liman şehirleri vasıtasıyla güneye ulaştırılıyordu. Kefe, Kili ve Akkirman gibi liman şehirlerine de güneyden önemli miktarda ipekli, pamuklu kumaşlar ile zeytinyağı, şarap ve kurutulmuş meyveler getirilerek Karadeniz'in kuzeyindeki iç kesimlere gönderiliyordu. XV. ve XVI. yüzylllarda kuzey-güney ticareti oldukça ivme kazanmıştır. $^{35}$

\footnotetext{
${ }^{26}$ Mustafa Akdağ, Türkiye’nin İktisadî ve İçtimaî Tarihi, C. I-II, Yapı Kredi Yayınları, İstanbul 2014, s. 483-6.

${ }^{27}$ W. Heyd, Yakın-Doğu Ticaret Tarihi, çev. Enver Ziya Karal, Türk Tarih Kurumu Basımevi, 2. Baskı, Ankara 2000, s. 75-6.

${ }^{28}$ Heyd, a.g.e., s. 79-80.

${ }^{29}$ Tuna Nehri o kadar güçlü bir nehirdir ki Avrupa'nın büyük bir kısmında rol oynadığı gibi, insanların yaşamlarını ve birbirleri arasındaki ilişkilerini de etkilemiştir. Tuna Nehri hakkındaki bilgilere Herodot'tan önce de rastlanılmaktadır. Hesiod eserinde Tuna Nehri'ni güzel akan olarak adlandırmaktadır. Romalılar ve Yunanlılar Tuna Nehri'nin sadece ağızlarını biliyor, kaynağını ise bilmiyorlardı. Onlar, Tuna'yı nehirlerin tanrısı olarak sayıyorlar ve Tuna Nehri'nin resimleri Roma paraları üzerinde yer alıyordu. Bkz. Oscar Ludwig Bernhard Wolff ve W. Henry Bartlett, Die Donau ihre Anwohner, Ufer, Städte, Burgen und Schlösser von ihrer Quelle bis zu ihrer Mündung, Leipzig 1843, s. 1.

${ }^{30}$ Heyd, a.g.e., s. 595.

${ }^{31}$ Gilles Veinstein, “İtalyanlar'dan Osmanlılar’a: Onaltıncı Yüzyılda Kuzey Karadeniz Kıyılarının Durumu”, çev. Akif Erdoğdu, Türk Dünyası Araştırmaları, S. 95, s. 153.

${ }^{32}$ Heyd, a.g.e., s. 595.

${ }^{33}$ Veinstein, “a.g.m.”, s. 152-66.

${ }^{34}$ Halil İnalcık, Osmanl İmparatorluğu'nun Ekonomik ve Sosyal Tarihi 1300-1600, C. I, ed. Halil İnalcık ve Donald Quataert, çev. Halil Berktay, Eren Yayıncılık, İstanbul 2000, s. 334-5.

${ }^{35}$ H. İnalcık, Osmanlı İmparatorluğu'nun...., C. I, s. 327-31; DİA Komisyonu, “a.g.m.”, s. 387.
} 
Akkirman'dan Lviv'e uzanan Boğdan yolundan önce doğunun malları Kefe ve Azak'tan Özü Nehri üzerinden Kiev, Kamaniçe ve Lviv'e taşınıyordu. Yani bu dönemde etkin bir rol üstlenen Kefe-Lviv yolu, XV. yüzyılın ikinci yarısından itibaren yerini Akkirman-Lviv güzergâhına bırakmıştır. Bu yol, esasen Bursa'dan başlayarak İstanbul ve Akkirman'1 takip etmek suretiyle kuzeye ulaşıyordu. Bu güzergâhta önemli ölçüde Müslüman tüccarlar da faaliyette bulunuyorlard1. XV. ve XVI. yüzy1llarda bu kuzey-güney ticaret yolunun en önemli ticari metası kürk ve esir idi. ${ }^{36}$ Fatih Sultan Mehmet'in 1475 yılında Kefe'yi fethetmesinden sonra Cenevizlilerin Karadeniz ticaretindeki etkinliği giderek azalırken onların yerini Osmanlı tebaası olan Ermeni, Rum, Yahudi ve Boğdanlılar almıştır. Neticede önceden Azak veya Kefe'den başlayarak Lviv'e uzanan eski Tatar Yolu önemini kaybetmiş ve onun yerini Akkirman'dan Lviv'e uzanan Boğdan Yolu almıştır. ${ }^{37}$

Osmanlı Devleti, esasen XVII. yüzyıldaki Kazak saldırılarına ${ }^{38}$ kadar Karadeniz hâkimiyeti konusunda çok fazla sıkıntı yaşamamış ve Karadeniz'deki egemenliğini 1774 Küçük Kaynarca Antlaşması'na kadar korumuştu. Bu zamana kadar Karadeniz, özel izinler dışında yabancı gemilerin bulundurulmasına kapalı bir deniz iken Küçük Kaynarca Antlaşması'nın ağır şartları ile ilk defa Rusya'nın kullanımına açılmıştır. ${ }^{39}$ Karadeniz'in bundan sonraki siyasi ve ticari durumu araştırmamızın konusunun dışında kaldığından burada mevzubahis edilmeyecektir.

Osmanlı Döneminde Karadeniz'de dört adet müstakil gümrük bölgesi bulunmaktaydı. Bunlardan birincisi Varna-Sinop arasındaki kıyıları kapsayan İstanbul gümrük bölgesi, ikincisi Sinop'tan Trabzon'a kadar uzayan Sinop gümrük bölgesi, üçüncüsü kuzeydoğuda Çerkezistan'a kadar uzayan Kefe Gümrük bölgesi ve dördüncüsü ise Karadeniz'in kuzeybatı kıyılarını kapsayan Akkirman gümrük bölgesidir. Araştırmamıza konu olan Kili gümrügü de 1538 yılından itibaren Cankirman, Bender, İbrail, Tulça, Hırsova... vb. gümrüklerle birlikte Akkirman gümrük bölgesi sınırları içerisinde yer almaktadır. Bu gümrüklerde en fazla işlem gören mallar şarap, tahıl, kumaş, baharat, canlı hayvan, et, balık, un olup bu iskelelerde köle ticareti de çok önemli bir yere sahipti. ${ }^{40}$

Tuna Nehri üzerinde yer alan Kili gümrüğü hem Karadeniz-Orta Avrupa ticareti ${ }^{41}$ yani doğu-batı ticareti, hem de İstanbul-Edirne-Kili-Akkirman yoluyla da kuzey-güney ticaretinde tahminimizce Kefe ve Akkirman'dan sonra Karadeniz kıyılarındaki en önemli iskelelerden birisi idi.

Buraya kadar Kili'nin bir yandan siyasi tarihi, diğer yandan da Karadeniz ticareti ve Kili gümrügü hakkında kısa bilgiler verilmiş olup bundan sonraki kısımda 25452 numaralı ve 1769 tarihli defterdeki verilerin değerlendirilmesi ile gümrügün gelir ve giderleri ayrıca gümrük gelirlerinin içerisinde en fazla dikkat çeken esir ticareti incelenecektir.

\section{1769 Yılında Kili Nezareti Gümrüğ̈̈'’nde Alınan Muhtelif Vergiler}

Kili’nin ve Kili Gümrüğü'nün kısa bir tarihçesinden sonra burada makalemizin temel kaynağı olan 25452 numaralı defterdeki veriler 1şığında 1769 yılında Kili Nezareti Gümrüğünün gelir ve giderlerini açıklamaya gayret edeceğiz. Öncelikle defterin Başbakanlık Osmanlı Arşivi'nde Bâb-1 Defterî, İstanbul Mukataası Kalemi Defterleri Kataloğu'nda bulunduğunu ifade etmeliyiz. Kili Nezareti Gümrügü, muhtemelen kuzey-güney ticaretinde İstanbul ile çok

\footnotetext{
${ }^{36}$ DİA Komisyonu, “a.g.m.”, s. 387.

${ }^{37}$ H. İnalcık, Osmanlı İmparatorluğu'nun ..., C. I , s. 334-5.

${ }^{38}$ Kazaklar ve İstanbul'a yapılan Kazak akınları hakkında detaylı bilgi için bkz. Yücel Öztürk, Özü'den Tuna'ya Kazaklar, Yeditepe Yayınevi, İstanbul 2004.

${ }^{39}$ Faruk Bilici, “Karadeniz (XVIII. Yüzyıl ve Sonrası)”, DIA, C. XXIV, İstanbul 2001, s. 388.

${ }^{40}$ H. İnalcık, Osmanlı İmparatorluğu'nun..., C. I, s. 246.

41 Orta Avrupa şehirleri Tuna Nehri vasıtasıyla Karadeniz'e oradan da boğazlar vasıtasıly Akdeniz'e bağlanmaktaydı. Bkz. Ardel, “a.g.m.”, s. 237.
} 
sıkı ilişki içerisinde bulunduğu ve coğrafi bakımdan da İstanbul'a yakın olduğundan dolayı Osmanlı Devlet Teşkilatı içerisinde İstanbul Mukataa'sına bağlanmış olabilir.

Defteri incelediğimizde 1769 yılında Kili Nezareti Gümrügü'nün gelirlerinin iki farklı şekilde kaydedildiği görülmektedir. Bunlardan birincisi, 12 Zilkade 1182'den başlayarak 19 Şaban 1183'e kadar (20 Mart 1769-18 Aralık 1769) olan yaklaşık on aylık süredeki Kili Gümrüğü İskelesi'nde işlem gören mallardan alınan resm-i pençik olmak üzere muhtelif gümrük vergilerinin oluşturduğu gelirlerdir. İkincisi ise gümrük gelirlerine ilave olarak gün ve ay esası yerine maktû hesaba göre kaydedilen Akkirman, Tulca, İsakçı, Maçin, Galati... vb mukataa gelirleri ile balıkhane, dalyan, ispenç ve resm-i geçid gibi vergi gelirleridir. Bu sebepten biz de burada Kili Nezareti Gümrüğü'nün gelirlerini defterdeki sistematiğe sadık kalarak iki farklı kapsamda değerlendirdikten sonra gümrügün toplam gelirini tespit etmeye gayret edeceğiz. Akabinde ise yine defterdeki veriler 1şı̆̆ında gümrüğün giderleri verilerek nihayet giderler hesaptan düşüldükten sonra Osmanlı hazinesine teslim edilen nakit veya kârın belirlenmesine çalışılacaktır.

25452 numaralı ve 1769 tarihli defterde dikkati çeken bir diğer husus ise Osmanlı para sisteminin değişmiş olmasıdır. 1300-1600 yıllarında yani Osmanlı klasik döneminde devletin en yaygın kullandığı para türü akçe iken defterin ait olduğu dönemde devlette yeni bir para düzeninin uygulandığı akçe yerine para ve kuruş sistemine geçildiği, defterin de bu doğrultuda kaydedildiği anlaşılmaktadır. İlgili defterdeki veriler öncelikle para olarak kaydedilmiş daha sonra ise ortaya çıkan meblağın kuruş olarak karşılığ 1 da kâtipler tarafindan özenle kaydedilmiştir. Ancak ne kadar dikkatli kaydedilmeye çalışıldıysa da bazen küsuratların yuvarlanmasından bazen de yapılan küçük hatalardan dolayı zaman zaman rakamlarda küçük sapmaların olduğu da görülmektedir. Defter hakkında verilen kısa bilgilerden sonra konunun daha iyi anlaşılabilmesi için defterin ait olduğu dönemde Osmanlı Devleti'nde tedavülde olan para sistemine göz atmamızın faydalı olacağını düşünüyoruz.

Her devlette olduğu gibi Osmanlı Devleti'nde de vergilerin alınmasında temel olan en önemli unsur elbette para düzenidir. XV. yüzyılın son çeyreğinde ilk altın sultani basılana kadar Osmanlı Devleti'nde en yaygın olarak kullanılan paralar gümüş akçe ve bakır mangırdan oluşmaktayd1. ${ }^{42}$ Osmanlı Devleti'nin temel para birimi olan akçenin kullanımı uzun yıllar boyunca sürmüş̧ür. Ancak XVI. yüzyılın son çeyreğindeki tağşiş ve fiyat artışlarının da etkisiyle XVIII. yüzyılın hemen başlarında yani III. Ahmed ${ }^{43}$ döneminden (1703-1730) itibaren akçe yerine ilk defa büyük boy Osmanlı kuruşu basılmıştır. Buna göre 1 Osmanlı kuruşu, 120 akçe veya 40 paraya eşit olmuştur. İlk Osmanlı kuruşları 25,6 gram olup bunun yaklaşık 16 gramı saf gümüş idi. ${ }^{44}$

İncelediğimiz defterde kâtiplerin gümrük gelirlerini -klasik dönemde kullanılan akçeden vazgeçerek- yeni geçilen para sistemine göre hem para hem de kuruş olmak üzere iki farklı türde kaydettiği görülmektedir. Söz konusu defterdeki veriler, 1 kuruşun 40 paraya karşılık geldiğini doğrulamaktadır. Şöyle ki; akçe yerine para bazında kaydedilen gelirleri 40'a böldüğümüzde ortaya çıkan meblağın defterde kuruş olarak kaydedilen meblă̆ ile bire bir aynı olduğu anlaşılmaktadır. Osmanlı kâtiplerinin Kili gümrügündeki gelirleri iki farklı para birimine göre kaydetmelerinin nedeni tahminimizce her iki para biriminin de o dönemde hâlâ Osmanlı iktisadi hayatında kullanılır olmasıdır.

Osmanlı para düzeni hakkında verilen bu bilgilerden sonra defterde en fazla dikkat çeken vergilerin başında gelen ve esir ticaretine ışık tutan resm-i pençiği açıklamaya gayret edeceğiz.

\footnotetext{
${ }^{42}$ Şevket Pamuk, Osmanlı Ekonomisi ve Kurumları, Türkiye İş Bankası Yayınları, İstanbul 2007, s. 70.

43 Ancak diğer bir görüşe göre ise kuruş ilk defa 1686 yılında Alman parası olan groschen den model alınarak basılmıştır. Bkz. H. Avni Şanda, Osmanlı İmparatorluğunda Para Problemleri, İstanbul Ticaret Odası Yayınları, İstanbul 1968, s. 10.

${ }^{44}$ Şevket Pamuk, "Kuruş", DİA, C. XXVI, İstanbul 2002, s. 458.
} 
Karadeniz limanları ile İstanbul arasında yapılan ticarette en fazla iktisadi öneme sahip olan köle ticareti ${ }^{45}$ ve bu ticaretten alınan vergi olan resm-i pençiğe burada özel bir önem vermek elzemdir.

\title{
3.1. Resm-i Pençik
}

Farsça beşte bir anlamına gelen penç ü yek veya penç-yek kelimeleri, Osmanlı Devleti tarafından pençik şeklinde kullanılmıştır. Esasen bu kavram Osmanlı askerî seferleri neticesinde ele geçirilen esirlerin beşte birinin devlet himayesine alınmasını ifade etmektedir. ${ }^{46}$ Pençik uygulamasının Osmanlılardan önce özellikle Abbasiler'den itibaren uygulandığı ve bilhassa Aydınoğulları'nda da uygulandığına dair kayıtlar mevcuttur. ${ }^{47}$ Osmanlı Devleti'ndeki ilk pençik uygulamasına baktığımızda, 1361 yılında Edirne'nin fethinden sonra Evrenos Gazi ve Hacı İlbeyi'nin Rumeli'deki hızlı fetihleri neticesinde savaş esirlerinin sayısında büyük bir artış olduğu görülür. Bunun neticesinde İslam adına gaza yapan gazilerden devlet için her beș esirden biri, ya da esir sayısı beş değil ise değerinin beşte birini toplamak suretiyle pençik uygulamasına geçilmiştir. Bundan dolayı devlet elinde toplanan esirlerin sayılarının artması ile sultan kapısında yeni bir askerî grup yani yeniçeriler ortaya çıkmıştır. ${ }^{48}$ Görüldüğü gibi I. Murad döneminde kurulan Yeniçeri Ocağına asker sağlamak için uygulanan pençik sistemi ile devşirme sistemi birbiriyle yakından alakalıdır. ${ }^{49}$

Burada İslam devletlerinde ve Osmanlı Devleti'nde var olan kölelik ve köle ticareti meselesinin açılanması, konunun daha iyi anlaşılması bakımından oldukça önemlidir. Halil İnalcık kölelik ve köle temini meselesini şu ifadelerle açıklamaktadır

\begin{abstract}
"İslam ülkelerinde, özellikle de Osmanlı toplumunda köleler hayatın vazgeçilmez bir parçasıydı. Sadece ev hizmetlerinde değil, askerî ve ekonomik alanlarda da çalıştırılıyorlardı. Daha önceki yüzyıllarda köle askeri seçkinler zümresinin ekime yeni açılan topraklarında tarımsal emek gücü olarak yaygın bir kullanım bulmuştu... Şu açıktır ki, Osmanlı İmparatorluğu'nda sadece devletin değil, ekonominin çeşitli kesimlerinin de temelinde kölelik vardı. Bu talep, İstanbul ve Bursa gibi büyük kent merkezlerinde çok canlı bir köle piyasası yarattığı gibi, esir ve cariyelerin belli başlı köle pazarlarında daima iyi para getirmesi sonucu, Osmanlı tarihinin ilk üç yüzyılı boyunca sınır boylarındaki akıncı gruplarının çapul ve esir alma faaliyeti için de güçlü bir dürtü oluşturuyordu. Ancak on altıncı yüzyılın ortalarından itibaren Osmanlılar, tam da iç piyasalarında köle talebinin giderek arttığı bir sırada, batı sınırlarında artık sert bir direnişle karşılaşır oldular. Bu yüzden Osmanlılara köle temini işi, esas olarak Kırım Tatarlarının eline geçti ve bunlar Polonya'ya Rusya'ya ya da Çerkezistan'a karşı yaygın köle akınlarına giriştiler." 50
\end{abstract}

Kuzey Karadeniz ile İstanbul arasında çok önemli bir yeri olan köle ticaretinde kölelerin temini sadece Çerkes ve Abhazlar değil bilakis Polonya, Litvanya ve Moskova civarına akın yapan Tatarlar tarafindan temin ediliyordu. ${ }^{51}$

Kuruluş devirlerinden itibaren Osmanlı Devleti'nde esir sayısının artması neticesinde ilerleyen dönemlerde bir esirin bedeli 125 akçeye kadar düşmüştür. ${ }^{52}$ Halil İnalcık, esir vergisinin kişi başına 256 akçe ya da 4 düka altını olarak tahsil edildiğini ve XV. yüzyılın ikinci yarısında Osmanlı şehirlerinde ortalama bir kölenin bedelinin 25 ile 50 altın arasında değiştiğini

\footnotetext{
${ }^{45}$ Karadeniz köle ticareti hakkında ayrıntılı bilgi için bkz. Zübeyde Güneş Yağcı, “16. Yüzyılda Kırım'da Köle Ticareti”, Karadeniz Araştırmaları, S. 8 (Kış 2005), s. 12-30; Zübeyde Güneş Yağcı, "İstanbul Gümrük Defterine Göre Karadeniz Köle Ticareti (1606-1607)”, History Studies, C. 3/2, 2011, s. 371-384.

${ }^{46}$ Mehmet Zeki Pakalın, Osmanlı Tarih Deyimleri ve Terimleri Sözlügü̈, C. II, Milli Eğitim Basımevi, İstanbul 1983, s. 766; Abdülkadir Özcan, "Pencik”, DİA, C. XXXIV, İstanbul 2007, s. 226.

${ }^{47}$ A. Özcan, “a.g.m.”, s. 226.

${ }^{48}$ H. İnalc1k, Devlet-i 'Aliyye..., s. 57-8.

49 Abdülkadir Özcan, "Devşirme", DİA, C. 9, İstanbul 1994, s. 254.

${ }^{50}$ H. İnalcık, Osmanlı Imparatorluğu'nun ..., C. I, s. 341-2.

${ }^{51}$ G. Veinstein, “a.g.m.”, s. 160.

52 Pakalın, a.g.e., s. 766.
} 
belirtmektedir. ${ }^{53}$ Bizim tespitlerimize göre, Kili Gümrüğ̈̈’nde 1769 yılında her bir esir için 110 para resm-i pençik alınmıştır. ${ }^{54}$

İncelediğimiz defterdeki gümrük gelirleri içerisinde resm-i pençik en çok dikkat çeken vergi kalemi olarak karşımıza çıkmaktadır. Yani Kili limanı, esir ticareti için çok önemli bir Karadeniz gümrügü idi. Defterin kayda alındığı tarih 1769 yılı olup, bu dönemde Küçük Kaynarca Antlaşması ile neticelenecek olan 1768-1774 Osmanlı-Rus savaşının cereyan etmesi tahminimizce gümrükte yüksek miktarda resm-i pençiğin alınmasının temel nedeni olmalıdır. 1769 yılında Kili Gümrüğü'nde tahsil edilen resm-i pençik aşağıda Tablo 1'de detaylı olarak gösterilmiştir:

Tablo 1: Kili Gümrügü̈’nde 1769 Yılında Alınan Resm-i Pençik ve Tahmini Esir Miktarı

\begin{tabular}{|l|c|c|c|}
\hline \multicolumn{1}{|c|}{ Aylar } & $\begin{array}{c}\text { Resm-i Pençik } \\
\text { (Para) }\end{array}$ & $\begin{array}{c}\text { 5/1 Oranında devletin vergi } \\
\text { olarak aldı̆̆ı tahmini esir } \\
\text { sayısı }\end{array}$ & $\begin{array}{c}\text { Gümrükten geçen toplam } \\
\text { esirin tahmini miktarı } \\
\mathbf{5 / 4}\end{array}$ \\
\hline Mart & 2085 & 19 & 76 \\
\hline Nisan & 6250 & 56 & 224 \\
\hline Mayıs & 6320 & 57 & 228 \\
\hline Haziran & 4190 & 30 & 120 \\
\hline Temmuz & 38.180 & 347 & 796 \\
\hline Ăgustos & 21.900 & 199 & 752 \\
\hline Eylül & 20.680 & 188 & 664 \\
\hline Ekim & 18.280 & 166 & 148 \\
\hline Kasım & 4120 & 37 & 52 \\
\hline Aralık & 1480 & 13 & $\mathbf{4 4 8 8 ~ K i s ̧ i}$ \\
\hline Genel Toplam & $\mathbf{1 2 3 . 4 8 5}$ Para & $\mathbf{1 1 2 2}$ Kişi & \\
\hline
\end{tabular}

Yukarıdaki Tablo 1'i yorumlaya başlamadan önce tablonun sistematiğini açıklamamız gerekir. Öncelikle resm-i pençiğin her beş esirden bir adedinin (5/1) devlet tarafından alınması şeklinde uygulandığını eğer esir sayısının 5'ten eksik veya fazla olduğu durumlarda tam karşılık gelmeyen kısmın nakit olarak tahsil edildiğini yukarıda belirtmiştik. Bundan dolayı tabloda ikinci sütunda nakit olarak gösterilen resm-i pençik miktarının her esir için alınan 110 paraya bölündüğünde, devletin vergi olarak aldığı tahmini esir sayısı ortaya çıkmaktadır. Bu verilerden yola çıkarak biz yukarıdaki Tablo 1'deki rakamları değerlendirdiğimizde 1769 yılında Kili Gümrüğü'nde alınan resm-i pençiğin miktarının 123.485 para olduğunu görürüz. Bu rakam da Kili Gümrügü̈nün o dönemde 667.887 para olan toplam gelirinin \%18,4'üne karşıllk gelmektedir. Buradan da anlaşılacağı gibi Tuna ağzında yer alan Kili Gümrüğü'nün 1769 yllındaki toplam gelirinin hemen hemen 5'te 1'i pençik vergisidir. Elbette bu düzeydeki pençik vergisi, her türlü metanın işlem gördüğü Kili Gümrüğü’nde en fazla gelir sağlayan tek kalemdir.

Defterdeki verilere göre, Kili Gümrüğü’nde alınan pençik vergisi toplamından yola çıkarak para bazındaki toplam miktarın her esir için tahsil edilen 110 paraya bölünmesi neticesinde tahmini esir sayısını belirleyebiliriz. Diğer taraftan pençik resminin 1/5 oranında alındığını düşündüğümüzde, hem devletin vergi olarak aldığı esir sayısını, hem de geri kalan 4/5 oranında esir sahibinin elinde bulunan esir sayısını tahmini olarak tespit edebiliriz. Zaten bu say1lar Tablo 1'deki üçüncü ve dördüncü sütunlarda verilmiştir. Son olarak devletin elindeki ve esir sahiplerinin elindeki esir sayılarını toplayarak 1769 yılında Kili Gümrügü̈nden geçen tahmini esir sayısı hakkında bilgi sahibi olabiliriz. Buna göre, Kili Gümrüğü’nde devlete vergi olarak verilen tahmini esir sayısı 1122 kişidir. Esir sahiplerinin elindeki tahmini esir sayısı ise 4488 kişidir. Bu iki rakamı topladığımızda 1769 yılında Kili Gümrügü’nden geçen toplam esir sayısının tahminen 5610 kişi olduğunu görüyoruz. Gümrükte devlete verilen esir sayılarını

\footnotetext{
${ }^{53}$ H. İnalcık, Osmanlı İmparatorluğu'nun ..., C. I, s. 339.

${ }^{54}$ B.O.A. Bâb-1 Defterî, İstanbul Mukataası Defterleri, D.İSM.d.25452, vrk.1.
} 
aylara göre değerlendirecek olursak, en fazla esirin 347 adet esir ile temmuz ayında, en az esirin ise 13 adet esir ile Aralık ayında verildiğini söyleyebiliriz. Ayrıca, toplam 10 ay boyunca tutulan gümrük kayıtlarından anlaşıldığına göre, pençik vergisinin ve esir sayısının en yüksek düzeye temmuz, ağustos, eylül ve ekim aylarında yani yaz ve sonbahar dönemlerinde ulaştığını görüyoruz. Bu dört ayın pençik vergisi gelirlerinin toplamı, 10 aylık gümrük kaydı içerisindeki toplam pençik vergisi miktarının \%80,2'sine tekabül etmektedir. Bu açıdan bakıldığında Kili Gümrüğü'nde esir ticaretinin en fazla bu dönemlerde yoğunlaştı̆̆ını söyleyebiliriz. Bunun nedenlerinden birisi de muhtemelen iklim şartları ile ilgilidir. Yani yaz ve sonbahar aylarında önemli miktarda bir esir sirkülasyonunun olduğu, kış aylarında ise esir miktarında önemli azalmanın olduğunu söyleyebiliriz. Zaten Tuna Nehri yılın büyük bir kısmında ulaşım ve ticaret için uygun iken yılda 3 ay boyunca donma veya buz kütlelerinin sürüklenmesi nedeniyle ulaşıma müsait değildir. ${ }^{55}$ Zaten bölge hakkında eser kaleme alan Moritz Busch da kış aylarında özellikle Balkanlar ve dağlık kesimlerde yoğun kar, dalgalanan nehirler ve bu nehirlerde köprü olmamasından dolayı seyahat etmenin neredeyse imkânsız olduğunu belirtmektedir. ${ }^{56}$ Defterdeki esir verileri ile bu bilgi örtüşmektedir.

\subsection{Diğer Vergiler}

İncelediğimiz gümrük defterinde en fazla dikkat çeken resm-i pençikten sonra öne çıkan damga-i esir, selamet-i sefine, resm-i duhan ve resm-i gön gibi diğer vergi gelirlerini burada tek bir başlık altında açıklamaya çalışacağız.

Selamet akçası da denilen bu vergi derbentler ve geçitlerden geçişlerde tahsil edilen bir vergi olup ${ }^{57}$ defterimizde geçen Selâmet-i Sefîne isimli verginin de bununla ilgili olacağını yani gümrüklere gelip giden gemilerin selameti ve güvenliği için tahsil edilmiş olabileceğini tahmin ediyoruz. Selâmet-i Sefîne adı altında Kili Nezareti Gümrügü’nden 1769 yılında on ay boyunca toplam 9852 para tahsil edildiğini görüyoruz. Diğer vergi gelirlerine de kısaca göz atacak olursak, esirlerin damgalanması neticesinde alınan damga-i esir vergisinin toplam 2690, tütünden alınan resm-i duhanın 3370 ve deriden alınan resm-i gönün ise 6587 para olarak tahsil edildiği anlaşılmaktadır. Tabi ki bu vergi toplamları, Kili Gümrüğü'ne gelip giden gemilerin hangi maldan ne miktarda getirip götürdüklerinin detaylı bir şekilde kaydedilmeden aksine gelen veya giden gemilerin "Sefine-i Ali Reis=160" şeklinde kaydedilmesinden ve yeterli teferruatın verilmeyişinden dolayı tüm emtia için alınan vergilerin toplamı içerisinde küçük bir meblağ olarak kalmaktadır. Ancak defterde resm-i pençik, damga-i esir, selamet-i sefine, resm-i duhan ve resm-i gön gibi vergilerin biraz önce bahsettiğimizden farklı olarak ayrı ayrı kaydedilmesi neticesinde en azından bu vergilerin toplamını tespit etme imkânı elde etmiş bulunmaktayiz.

\section{Kili Nezareti Gümrüğü’nün 1769 Yılındaki Toplam Geliri ve Giderleri}

Burada ilk olarak Kili Nezareti Gümrügü’nün gümrük gelirleri ile maktu olarak alınan mukataa gelirleri olmak üzere iki kısımdan oluşan gelirlerinin ayrı ayrı tablolarda verildikten sonra toplanması suretiyle gümrüğün toplam gelirleri belirlenecek ve sonrasında ise gümrüğün giderleri verilerek gümrüğün gelir ve gider haritası çıkarılmaya çalışılacaktır. Yukarıda on ay boyunca toplanan ve oldukça dikkat çeken resm-i pençik ve diğer vergi gelirlerini açıklayıp meblağlarını verdikten sonra bu bölümde ise Kili Nezareti Gümrüğü'nün 1769 yılındaki kayitlara göre on aylık olarak kaydedilen gelirlerini aylara göre belirlemeye gayret edeceğiz. Kili Nezareti Gümrüğü'nün maktu gelirleri ise bu gelirlere daha sonra eklenecektir. Buna göre, Kili Nezareti Gümrüğü’nün 1769 yllı 12 Zilkade 1182'den 19 Şaban 1183'e kadar (20 Mart 1769-18 Aralık 1769) yani on aylık süreçteki gelirleri Tablo 2'de gösterilmiştir.

\footnotetext{
${ }^{55}$ Ardel, “a.g.m.”, s. 237.

${ }^{56}$ Moritz Busch, Reisehandbuch für Rumelien, Die Untere Donau, Anatolien, Syrien, Palästina, Rhodus, und Cypern, Triest 1870, s. 271.

${ }^{57}$ Pakalın, a.g.e., C. III, s. 153.
} 
Tablo 2: Aylara Göre Kili Nezareti Gümrüğü’nün 1769 Y1lındaki Gelirleri

\begin{tabular}{|l|l|c|c|}
\hline \multicolumn{2}{|c|}{ Aylar (Hicri ve Miladi) } & Gelir (Para bazında) & Gelir (Kuruş bazında) \\
\hline Zilkade & Mart & 23.525 & 588 \\
\hline Zilhicce & Nisan & 41.252 & 1031 \\
\hline Muharrem & Mayıs & 31.043 & 776 \\
\hline Safer & Haziran & 35.177 & 878 \\
\hline Rebiyülevvel & Temmuz & 76.820 & 1920,5 \\
\hline Rebiyülahir & Ağustos & 67.570 & 1689 \\
\hline Cemaziyelevvel & Eylül & 65.600 & 1639,5 \\
\hline Cemaziyelahir & Ekim & 59.220 & 1480,5 \\
\hline Recep & Kasım & 83.440 & 2086 \\
\hline Şaban & Aralık & 184.240 & 4606 \\
\hline \multicolumn{2}{|c|}{ Genel Toplam } & $\mathbf{6 6 7 . 8 8 7}$ & $\mathbf{1 6 . 6 9 4 , 5}$ \\
\hline
\end{tabular}

Tablo 2'yi yorumlayacak olursak, 1769 yllında Kili İskelesi'nin gümrükten elde ettiği gelirlerin toplamı 667.887 para olup bu meblağ da 16.694,5 kuruş veya 2.003 .340 akçeye karş1l1k gelmektedir. Defterdeki verilere göre, gümrük gelirlerinin en fazla olduğu aylar 184.240 para ile Aralık ve 83.440 para ile Kasım ayları iken en az olduğu aylar ise 23.525 para ile Mart ve 31.043 para ile Mayıs aylarıdır. Diğer aylarda ise gümrüğün geliri 40.000 para ile 76.000 para arasında değişmektedir. Yine Tablo 2'deki verilere göre, Kili Nezareti Gümrük gelirlerinin Temmuz ayından itibaren önceki aylara oranla yaklaşı iki kat yükseldiğini söyleyebiliriz. Ancak gümrük gelirlerinin en yüksek olduğu ayın Aralık olması burada ilgi çekicidir. Mevsimin kış olmasına rağmen Kili Nezareti Gümrüğü'nün en yüksek düzeye ulaşması hakkında herhangi bir yeterli açıklama tespit edebilmiş değiliz.

Kili Nezareti Gümrügü’nün 1769 yılındaki gümrük gelirlerinden sonra buraya bağlı diğer mukataa, iskele ve çeşitli vergi kalemlerinden alınan yıllık maktu gelirler aşağıda Tablo 3'te verilmiştir. Yukarıda Tablo 2'de gümrük gelirlerinin toplamı 16.694,5 kuruş olarak hesaplanmasına rağmen incelediğimiz defterin en son kısmında mahsulat ve masarifat şeklinde gelir ve giderlerin ayrıldığı kısmında bu toplam 16.656,5 kuruş olarak verilmiştir. Aradaki 38 kuruşluk farkın sebebinin muhtemelen para olarak toplanan vergi gelirlerinin kuruşa çevrilmesindeki küsuratlardan kaynaklanmış olabileceğini tahmin ediyoruz. Biz burada kendi toplamlarımız yerine defterde geçen rakamları baz almış bulunmaktayız. Bu yüzden de Tablo 3'ün ilk satırında 16.694,5 kuruş yerine 16.656,5 kuruş yazmış bulunmaktayız. Buna göre, Kili Nezareti Gümrüğü'nün toplam gelirleri aşağıda Tablo 3 'te gösterilmiştir.

Tablo 3: Kili Nezareti Gümrügü’nün 1769 Yllındaki Toplam Gelirleri

\begin{tabular}{|l|l|}
\hline \multicolumn{1}{|c|}{ Gelir Türü } & \multicolumn{1}{|c|}{ Para } \\
\hline Aylara göre gümrükten alınan muhtelif vergiler toplamı & $16.656,5$ \\
\hline Mahsul-i balıkhane ve dalyanhâ an ecnâs-1 mâhi & 8386 \\
\hline İmdâd-1 dalyan ber cânib-i varoş ber mûtâd-1 kadîm & 300 \\
\hline Hâsıl-1 ihtisâb maa bacahane ve ispenç & 3350 \\
\hline Âşâr-1 şer'iyye ve maktu-1 kurâ & 5048,5 \\
\hline Berâ-yı tahmis maa kahvehane-i nefs-i Kili & 100 \\
\hline An mâl-i geçid-i nefs-i Kili & 150 \\
\hline An mâl-i geçid-i karye-i Hitay? & 70 \\
\hline Resm-i bâd-1 hevâ ve beytü’l-mâl-i gâib & 436 \\
\hline Hâsıl-1 mukâtaa-i Akkirman ve tevâbihâ ber mûceb-i icmal & 8918 \\
\hline Mahsûl-i mukâtaa-i Tulca & 4350 \\
\hline Mahsûl-i mukâtaa-i İsakçı & 1294 \\
\hline Mahsûl-i mukâtaa-i Maçin & 1500 \\
\hline Mahsûl-i mukâtaa-i Galati maa Tuna? Abad & 1886 \\
\hline Genel Toplam & $\mathbf{5 2 . 4 4 5}$ \\
\hline
\end{tabular}


Tablo 3’teki verilere göre, 1769 y1lında Kili Nezareti Gümrüğü’nün toplam geliri 52.445 kuruştur. Bu meblağın içerisinde en fazla paya sahip olan kalem 16.656,5 kuruş ile gümrükten alınan vergilerdir. Bu gümrük vergilerini ise 8918 kuruş ile Akkirman mukataasının gelirleri, 8386 kuruş ile sancak dâhilindeki balıkhane ve dalyanlardan alınan vergi gelirleri ve 5048,5 kuruş ile sancağa tabi köylerden maktu olarak alınan öşür vergisi gelirleri takip etmektedir. Buradaki bilgilerden Akkirman, Tulca, İsakçı, Maçin ve Galati gibi mukataaların o dönemde Kili Nezareti Gümrüğü'ne tâbi olduğunu anlıyoruz. Bu da Tuna ağzında yer alan Kili Nezareti Gümrüğü'nün 1769 yılında sadece Tuna Nehri havzasındaki mukataaları değil, bilakis Akkirman gibi Turla Nehri (Dinyester) ağzındaki mukataaları da kapsadığını göstermektedir.

İncelediğimiz defter esasında bir gümrük defteri olsa da yukarıdaki gelir kalemlerine baktığımızda ispenç, öşür, bâd-ı hevâ, mukataa ve resm-i geçit gibi birçok maktu vergi gelirinin de gümrük gelirlerine eklenerek sonrasında da yapılan harcamalar verilerek âdeta mufassal bir muhasebe defterine dönüştüğü anlaşılmaktadır. 1769 yılında Kili Nezareti Gümrügünün gelirleri bu şekilde iken giderler ise Tablo 4'te gösterilmiştir.

Tablo 4: Kili Nezareti Gümrüğü’nün 1769 Yılındaki Toplam Giderleri

\begin{tabular}{|l|l|}
\hline \multicolumn{1}{|c|}{ Harcama Türü } & \multicolumn{1}{|c|}{ Para } \\
\hline İhrâc-1 masârifât-1 cümle ber mûceb-i icmâl & 5845 \\
\hline İhrâc-1 masârif-i dalyan & 3641 \\
\hline İhrâc-1 masârif-i öşr ve icâre-i zemîn & 766,5 \\
\hline İhrâc-1 vezâif ve kalemiyye ve peşîn-i mîrî & $32.176,5$ \\
\hline Genel Toplam & $\mathbf{4 2 . 4 2 9}$ \\
\hline
\end{tabular}

Buna göre, 1769 y1lında Kili Gümrüğü’nün giderlerinin toplamı 42.429 kuruştur. ${ }^{58}$ Burada gümrüğün harcamaları içerisinde en yüksek payı olan kısım 32.176,5 kuruş ile görevlilerin ve kalemiye giderleridir. Bu giderler toplam giderin yaklaşık \%76'sına tekabül etmektedir. Buradan da anlaşılacağı üzere Kili Nezareti Gümrüğü dâhilinde görev yapan devlet görevlilerin hem sayısının fazla olduğunu hem de gümrügün rutin işleyişi esnasında büyük bir harcamaya gerek duyduğunu tahmin ediyoruz. Gümrüğün diğer giderleri ise 5845 kuruş ile diğer masraflar ve 3641 kuruş ile dalyan masrafları ve son olarak 766,5 kuruş ile öşür ve zemin icarı masraflarıdır. Kili Nezareti Gümrügünün toplam gelir ve giderleri ise aşağıda Tablo 5'te gösterilmiştir.

Tablo 5: Kili Nezareti Gümrüğü’nün 1769 Yılındaki Gelir ve Giderleri

\begin{tabular}{|l|c|c|}
\hline \multicolumn{1}{c|}{ Türü } & Kuruş & Para \\
\hline Gelirlerin toplamı & 52.445 & 2.097 .800 \\
\hline Giderlerin toplamı & 42.429 & 1.697 .160 \\
\hline Hazineye teslim edilen & $\mathbf{1 0 . 0 1 6}$ & $\mathbf{4 0 0 . 6 4 0}$ \\
\hline
\end{tabular}

İncelediğimiz defterdeki verileri baz alarak oluşturduğumuz Tablo 4'e göre, 1769 yılında Kili Nezareti Gümrüğ̈̈'nün toplam geliri 52.445 kuruş iken toplam gider ise 42.429 kuruştur. Buna göre gümrüğün gelirlerinin yaklaşık \%81'i gider olarak görülmektedir. Geri kalan 10.016 kuruş ise toplam gelirin ancak \%19'una tekabül etmekte ve hazineye teslim edilen kar olarak görülmektedir. Tüm bu verilerden 1769 yılında Kili Nezareti Gümrügü̈nün gelir ve giderlerinin birbirine esasında çok yakın olduğu ve dolayısıyla devlete teslim edilen kar payının ise gayet az olduğu anlaşılmaktadır.

Sonuç olarak baktığımızda her ne kadar Kili, Tuna Nehri’nin Karadeniz ağzında yer alsa ve Tuna Nehri vasıtasıyla Karadeniz-Orta Avrupa ticaretinde öne çıksa da, buranın, Kuzey ticareti, Osmanl1-Rus ticareti ve Anadolu ticaretinde de etkili olduğunu, incelediğimiz defterde

\footnotetext{
${ }^{58} \mathrm{Bu}$ meblağı para ve akçeye çevirdiğimizde ortaya çıkan rakamlar ise 1.697 .160 para ve 5.091 .480 akçedir.
} 
geçen Benderli, Lofçalı, İbrailli, Varnalı, Kayserili, Kırımlı, Rusçuklu, İstanbûli, Akkirmânî, İzmirli, Kastamonulu, Kavalalı, Anadolulu, Edirneli, Karamanlı, Galatalı, Sürmeneli, Urlalı, Nogaylu, Giritli, Ziştovili, Babadağlı, Vidinli, Şumlulu... vb. tüccarların olmasından dolayı o bölgelere de hitap ettiğini tahmin ediyoruz. Defterde az miktarda da olsa Yahudi ve Hristiyan tüccarların da isimleri kayıtlıdır.

Defterdeki verilere göre, 1769 y1lında Kili İskelesi gümrüğünde esir, mum, incir, duhan, gön, asel, bastırma, kahve, pirinç, hamr, keçe, iplik, helva, şeker, sahtiyan, revgan-1 sade, revgan-1 zeyt, revgan-1 şem, cild-i ganem ve balmumu gibi çeşitli ticari emtianın işlem gördüğü anlaşılmaktadır. Tüm bu verilerden Kili gümrügünün her türlü emtianın gelip geçtiği, dolayısıyla da hem bölgesel hem de kuzey-güney esir ticaretinde çok önemli bir suyolu gümrüğ̈ olduğunu söyleyebiliriz.

\section{Kaynakça}

\section{Arşiv Belgeleri}

B.O.A. Bâb-1 Defterî, İstanbul Mukataası Defterleri, D.İSM.d.25452.

\section{Tetkik Eserler}

Akdağ, Mustafa, Türkiye'nin İktisadî ve İçtimaî Tarihi, C. I-II, Yapı Kredi Yayınları, İstanbul 2014.

Ardel, Ahmet, “Karadeniz”, IA, C. 6, Eskiş̧ehir 1997, s. 230-8.

Bilici, Faruk, "Karadeniz (XVIII. Yüzyıl ve Sonrası)”, DİA, C. 24, İstanbul 2001, s. 388-90.

Bulunur, Kerim İlker, "Osmanlı Dönemi Karadeniz Ticaret Tarihine Katkı: Akkirman Gümrüğü (1505)”, Omeljan Pritsak Armağanı- A Tribute To Omeljan Pritsak, Sakarya Üniversitesi, 2007, s. 525-81.

Busch, Moritz, Reisehandbuch für Rumelien, Die Untere Donau, Anatolien, Syrien, Palästina, Rhodus, und Cypern, Triest 1870.

Decei, Aurel, “Karadeniz (Tarih)”, İA, C. 6, Eskişehir 1997, s. 238-46.

DİA Komisyonu, “Karadeniz”, DİA, C. 24, İstanbul, s. 386-8.

Finkel, Caroline, Rüyadan Imparatorluğa Osmanlı İmparatorluğu'nun Öyküsü 1300-1923, çev. Zülal Kılıç, Timaş Yayınları, İstanbul 2010.

Guboğlu, Mihail, “Fatih'in Ştefan Çel Mare Üzerine İki Boğdan Seferi (1474-1476)”, Belleten, C. XLVII, S. 185, Ankara 1984, s. 138-94.

Güneş Yağcı, Zübeyde, “16.Yüzyılda Kırım'da Köle Ticareti”, Karadeniz Araştırmaları, S. 8 (Kış 2005), s. 12-30.

Güneş Yağc1, Zübeyde, "İstanbul Gümrük Defterine Göre Karadeniz Köle Ticareti (16061607)”, History Studies, C. 3/2, 2011, s. 371-84.

Hammer, Joseph Von, Osmanlı Imparatorluğu Tarihi, C. I, İlgi Kültür Sanat Yayınları, İstanbul 2007.

Heyd, W., Yakın-Doğu Ticaret Tarihi, çev. Enver Ziya Karal, Türk Tarih Kurumu Basımevi, 2. Bask1, Ankara 2000.

Hoca Sadettin Efendi, Tacü't-Tevarih, haz. İsmet Parmaksızoğlu, C. II, Kültür Bakanlığ1 Başvuru Kitapları, Eskişehir 1992. 
İnalc1k, Halil, Devlet-i 'Aliyye-Osmanlı İmparatorluğu Üzerine Araştırmalar I, Türkiye İş Bankası Kültür Yayınları, İstanbul 2009.

İnalcık, Halil, Osmanl Imparatorluğu'nun Ekonomik ve Sosyal Tarihi 1300-1600, C. I, ed. Halil İnalcık ve Donald Quataert, çev. Halil Berktay, Eren Yayıncılık, İstanbul 2000.

Jorga, Nicolae, Osmanlı Imparatorluğu Tarihi, çev. Nilüfer Epçeli, C. II, Yeditepe Yayınları, İstanbul 2009.

Kantemir, Dimitri, Osmanlı Imparatorluğu'nun Yükseliş ve Çöküş Tarihi, düz. Erkan Ünlücan, C. I, İstanbul 2002.

Maxim, Mihai, “Kili”, DİA, C. 26, İstanbul 2002, s.1-3.

Maxim, Mihai, “Tuna”, DIA, C. 41, İstanbul 2012, s. 372-4.

Mehmed Neşri, Neşri Tarihi, haz. Mehmet Altay Köymen, C. II, Kültür ve Turizm Bakanlığı Yayınları, Başbakanlık Basımevi, Ankara 1984.

Mustafa Nuri Paşa, Netayicü’l-Vukuat, C. I-II, sad. Neşet Çağatay, Türk Tarih Kurumu Basımevi, Ankara 1992.

Müller, Adelbert, Die Donau vom Ursprunge bis zu den Mündungen, Verlag von G.Joseph Manz, Regensburg 1839.

Özcan, Abdülkadir, "Devşirme”, DİA, C. 9, İstanbul 1994, s. $254-7$.

Özcan, Abdülkadir, “Pencik”, DİA, C. 34, İstanbul 2007, s. 226-8.

Öztürk, Yücel, Özü’den Tuna'ya Kazaklar, Yeditepe Yayınevi, İstanbul 2004.

Pakalın, Mehmet Zeki, Osmanlı Tarih Deyimleri ve Terimleri Sözlüğü, C. II, Milli Eğitim Basımevi, İstanbul 1983.

Pamuk, Şevket, "Kuruş", DİA, C. 26, İstanbul 2002, s. 458-9.

Pamuk, Şevket, Osmanlı Ekonomisi ve Kurumları, Türkiye İş Bankası Yayınları, İstanbul 2007.

Pamuk, Şevket, Osmanlı Imparatorluğu'nda Paranın Tarihi, Tarih Yurt Vakfı Yayınları, İstanbul 2012.

Şanda, H. Avni, Osmanlı Imparatorluğunda Para Problemleri, İstanbul Ticaret Odas1 Yayınları, İstanbul 1968.

Uzunçarş11ı, İsmail Hakkı, Osmanlı Tarihi, C. II, Türk Tarih Kurumu Basımevi, Ankara 1998.

Veinstein, Gilles, “İtalyanlar'dan Osmanlılar'a: Onaltınc1 Yüzyılda Kuzey Karadeniz Kıyılarının Durumu”, çev. Akif Erdoğdu, Türk Dünyası Araştırmaları, S. 95, s. 152-66.

Wolff, Oscar Ludwig Bernhard ve W. Henry Bartlett, Die Donau ihre Anwohner, Ufer, Städte, Burgen und Schlösser von ihrer Quelle bis zu ihrer Mündung, Leipzig 1843. 